\title{
Rituximab Regimen
}

National Cancer Institute

\section{Source}

National Cancer Institute. Rituximab Regimen. NCI Thesaurus. Code C160115.

An immunotherapy regimen consisting of rituximab that may be used in the treatment of chronic lymphocytic leukemia (CLL), small lymphocytic, diffuse large B-cell, follicular (grade 1-2), and mucosa-associated lymphoid tissue (MALT) lymphomas. 